\title{
Toward a climate for work resumption: The nonmedical determinants of return to work
}

Citation for published version (APA):

D'Amato, A., \& Zijlstra, F. (2010). Toward a climate for work resumption: The nonmedical determinants of return to work. Journal of Occupational and Environmental Medicine, 52(1), 67-80.

https://doi.org/10.1097/JOM.0b013e3181c75291

Document status and date:

Published: 01/01/2010

DOI:

10.1097/JOM.0b013e3181c75291

Document Version:

Publisher's PDF, also known as Version of record

Document license:

Taverne

Please check the document version of this publication:

- A submitted manuscript is the version of the article upon submission and before peer-review. There can be important differences between the submitted version and the official published version of record.

People interested in the research are advised to contact the author for the final version of the publication, or visit the DOI to the publisher's website.

- The final author version and the galley proof are versions of the publication after peer review.

- The final published version features the final layout of the paper including the volume, issue and page numbers.

Link to publication

\footnotetext{
General rights rights.

- You may freely distribute the URL identifying the publication in the public portal. please follow below link for the End User Agreement:

www.umlib.nl/taverne-license

Take down policy

If you believe that this document breaches copyright please contact us at:

repository@maastrichtuniversity.nl

providing details and we will investigate your claim.
}

Copyright and moral rights for the publications made accessible in the public portal are retained by the authors and/or other copyright owners and it is a condition of accessing publications that users recognise and abide by the legal requirements associated with these

- Users may download and print one copy of any publication from the public portal for the purpose of private study or research.

- You may not further distribute the material or use it for any profit-making activity or commercial gain

If the publication is distributed under the terms of Article $25 \mathrm{fa}$ of the Dutch Copyright Act, indicated by the "Taverne" license above, 


\title{
Toward a Climate for Work Resumption: The Nonmedical Determinants of Return to Work
}

\author{
Alessia D'Amato, PhD, and Fred Zijlstra, PhD
}

\begin{abstract}
Objective: People who have been on long-term absence from work because of ill health usually have reduced chances to resume work again. Nevertheless, little is known about its causal factors. The aim of this study is to present and test an empirical model to predict return to work of employees who are long-term absent for physical- or mental ill health reasons. Method: A longitudinal study has been performed with a sample of long-term absents in five European countries $(N=1460)$. Results: Health improvement is necessary but it alone not sufficient as precondition for return to work. Psychological factors (ie, self-efficacy, depression) and organizational factors have the highest impact. Conclusions: A climate for work resumption and its implications for personnel management practices to reduce/prevent workers to remain in absence leave when the medical symptoms have disappeared are discussed.
\end{abstract}

W ork and health are important for people, the organization and the society as a whole. Ill health causes sickness absence, which constitutes high economic and individual costs. For that reason, sickness absence has generated a wealth of research that focused mainly on finding factors that contribute to sickness absences (both short-term and long-term absenteeism. ${ }^{1-5}$ The acknowledgment of the fact that absentees need to return to work (RTW) has become of interest, hence, the introduction of the concept of "disability management (DM)." The term DM refers to the deploy ability of people at work, employability, and competences (see Conference on Disability Management-International Forum on Disability Management, Berlin, 2008). The main focus of $\mathrm{DM}$ is to reduce absenteeism caused by ill health and to reduce the influx of recipients of occupational disability benefits by providing support to RTW. ${ }^{6-13}$ The idea that workers on sickness absence should RTW is in itself not new. The problem was already addressed some 40 years ago. ${ }^{14}$

One of the most important political goals of the European Union (EU) is to stimulate that all citizens take part in society and that they can earn their own cost of living and avoid economic and social deprivation. ${ }^{15}$ For that reason, the EU cannot accept that long-term absentees (LTAs) are at risk to be sidelined in society. Sickness absenteeism is accompanied with high social and financial costs and puts a burden on the national systems for social security. To keep the social security systems sustainable, these costs need to be reduced.

Exploring ways that facilitate RTW after long-term absenteeism is an important political and scientific objective, but notwithstanding the relevance of this topic, the literature is limited. ${ }^{16}$ Only in recent years, the scientific interest on this subject has

From CENTRUM Católica, (Dr D'Amato) Pontificia Universidad Católica del Perú, Lima, Perú; and Faculty of Psychology (Dr Zijlstra), University of Maastricht, Maastricht, The Netherlands.

Address correspondence to: Alessia D'Amato, PhD, CENTRUM Católica, Pontificia Universidad Católica del Perú Calle Daniel Alomia Robles 125-129, Los Alamos de Monterrico, Santiago de Surco, Lima 33-Perú; E-mail: adamato@pucp.edu.pe.

Copyright (C) 2010 by American College of Occupational and Environmental Medicine

DOI: 10.1097/JOM.0b013e3181c75291 increased. ${ }^{17-19}$ The mainstream of literature in the area of "work and health" has focused on determining causes for ill health, ${ }^{20}$ and there is a wealth of literature highlighting the relationship between work characteristics and the risk for (mental) health problems. This literature demonstrates that particular characteristics of people's jobs constitute a risk for mental health problems (MHs). For instance, "lack of job control" can lead to depressive feelings and anxiety. ${ }^{20-22}$

The literature on work rehabilitation and work resumption, as far as it is available, seems to be restricted to people with physical health problems (PHs), ie, coronary heart problems, people with physical disabilities, and neurological and brain damages. ${ }^{16}$

The group with mental health complaints seems to be underrepresented in this literature, while this group has increased considerably over the last decade, in particular people with stressrelated MHs (ie, burnout and so on). Mental and behavioral disorders are currently in some countries the most frequently mentioned reason for long-term sickness absence from work and responsible for approximately one third of long-term sickness absence. Stress is probably the most important underlying problem in this diagnostic category. Workers on long-term absence as a result of stress have a very low probability of returning to work. Current rehabilitation and RTW models are often developed on the basis of mainly physical conditions and, as a result, are ineffective in responding to the needs of workers experiencing long-term absence because of stress-related psychological problems. ${ }^{23}$ According to the Health and Safety Executive in the UK, stress-related conditions is one of the largest groups of work-related health conditions (www.hse. gov.uk/statistics/causdis/stress), with an estimated loss of 13.5 million lost working days per year. ${ }^{24}$

The body of literature on PHs suggests that psychological factors and individual health situation have an effect on people's decisions concerning absenteeism and work resumption. There is also an understanding that contextual aspects (ie, living and working conditions, organizational policies, income, social security issues, etc.) might have an effect. ${ }^{25}$ Therefore, these factors need to be taken into account when studying conditions concerning work resumption

A key challenge for research in RTW is in fact to identify the individual variables and organizational and contextual characteristics that influence RTW. The aim of this study is to develop a framework that helps to understand the process of work resumption and to compare and contrast sickness absence for PHs and MHs. This framework should incorporate psychological factors and contextual aspects, in particular organizational characteristics.

\section{Sickness Absence and Work Resumption}

A recent study by Leiter et $\mathrm{al}^{26}$ demonstrated that people's behavior is strongly influenced by their perception of the environment. In this study, focused on safety behavior, it was revealed that safety is not just an individual problem but it is also a matter of their context. In the same vein, one can argue that not only the individuals perception of their health is important but also the influence of the environment, ie, the organizational context, has a strong effect on people's decision to RTW. This view is in line with a model on absenteeism behavior as presented by Allegro et al. ${ }^{2}$ This model states that reporting sick is the result of a decision in which various 


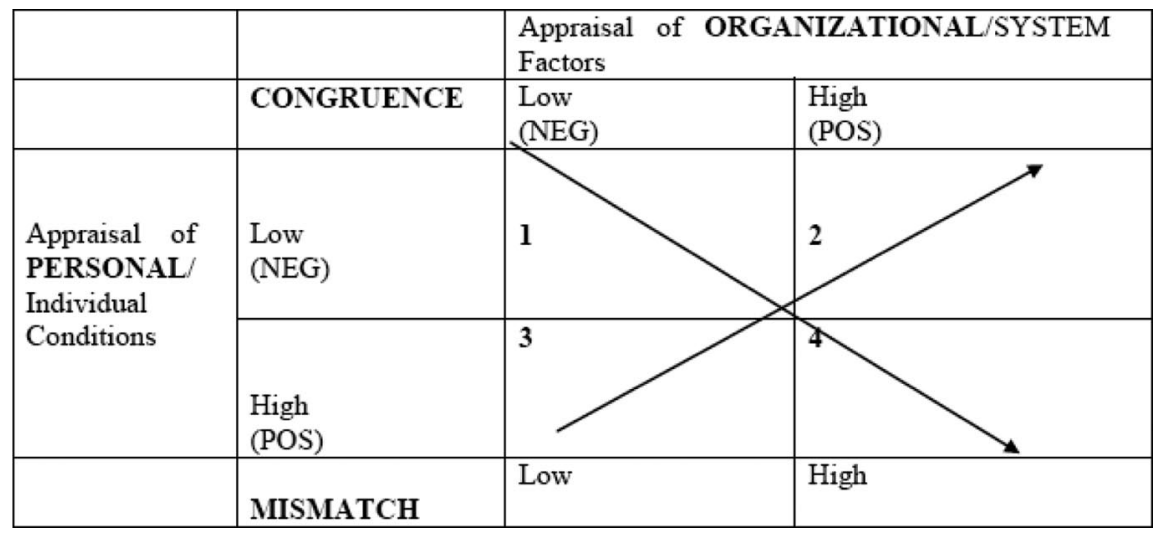
characteristics and RTW.

elements play a role, such as the opportunity to stay home (how badly is one needed at work?), the situation at home (is it possible, desirable to stay home?), and the health situation (how bad is one's health?). The actual decision to report ill is a resultant in which these aspects are weighted and is represented as passing a threshold. ${ }^{2}$ The underlying theoretical framework is the Theory of Reasoned Action (TRA). ${ }^{27-29}$ The TRA states that people's attitudes and believes concerning aspects of their environment have a strong influence on the decision they take. One of the implications of the TRA is that people need to have a strong belief that a successful RTW is possible. Thus, apart from psychological factors, organizational factors also do play an important role in the RTW process.

As we previously observed, studies focusing on work resumption are scarce, ${ }^{16}$ ) in particular, as far as resuming work after absence for mental health reasons is concerned, and they tend to focus solely on the individual. Research indicates that RTW can be a cumbersome process, with sometimes many hurdles to be taken. ${ }^{30}$ This may be because of changes that have taken place during the period of absence. Changes can not only be in the organization (ie, job has been taken over by somebody else, etc) but also the absentee may have changed, or at least his working capacities. In particular, when health reasons have caused the absenteeism, this may have resulted in (permanent or temporary) changes in the employee's functional capabilities (disability, functional limitations, etc.). This may justify the question of whether that person can resume in the same job, with or without specific adjustments. Depending on the functional limitations of the person adjustments, varying from providing a wheelchair ramp to job redesign may be needed. Nevertheless, this shift can have organizational consequences as well. The willingness and speed with which organizations can implement the needed adjustments evidently will affect work resumption of the employee or the organizations' DM policy.

$\mathrm{DM}$ is a structured reintegration policy in the organization, giving responsibilities to a DM coordinator, with the goal to increase the employability and competences through a specific approach (modification of the duties for people resuming work after a sickness period, investments both in the deploy ability of personnel and the provision of a healthy and working conditions designed to prevent illness, etc.).

\section{Appraisal of Individual Characteristics and Contextual Factors}

The conclusion from aforementioned must be that, from a psychological perspective, both the following aspects need to be optimal: a) the person's appraisal of organizational aspects and b) the appraisal of self (ie, own situation), to predict successful RTW. When people perceive the characteristics of the organization as positive and also perceive their individual aspects as positive, this will enhance the likelihood of returning to work. On the other hand, it is quite likely that a mismatch of the combination of personal and organizational characteristics will reduce the chance to RTW. This is illustrated in Fig. 1.

Figure 1 can be seen as an operationalization of Ajzen and Fishbein's TRA in the context of work resumption. The likelihood that employees will RTW after a period of absence is influenced by two main factors: first, the perception of having recovered from the illness and, second, the belief that they will be able to perform work activities. Beliefs about the context are very important, as was also demonstrated in the study by Leiter et al. ${ }^{26}$

In this scheme, the fourth quadrant represents the situation in which the individuals appraise their own situation positively and also the characteristics of the organization. When a person is situated in this quadrant, the outcome will likely be work resumption. Nevertheless, if the appraisal of one of the two conditions is not positive, this will make work resumption less likely.

The other three quadrants represent situations where there is not a match between positive appraisal of the personal situation and positively perceived organizational characteristics. Quadrant 1 represents a situation where the person thinks he/she is not yet ready to resume work again and also has a negative perception of the organization (eg, no supportive supervisor or colleagues or both); while quadrant 2 represents the situation where the organization may be supportive (ie, have policies in place, job is attractive, etc), but the absentee doesn't feel up to resuming work yet. People in quadrant 3 feel that they are not ready and also the organization's aspects (level of support, characteristics of the job etc) are perceived negatively.

Thus, the implication is that improvement of health is nevertheless a necessary condition for RTW. If people have the reassurance or at least the feeling that their health is improved compared with the spell of sickness that induced work absence, they are more likely to RTW. Thus, our first hypothesis is

\section{Hypothesis 1:}

Among LTAs, do people who believe that their health has improved have a higher frequency to RTW than those people who believe that their health has not improved. ${ }^{2}$

As predicted by the TRA, ${ }^{27,28}$ both the appraisal of personal circumstances and the organizational aspects contribute to work resumption. As a consequence, people need to believe that they can RTW to grant a positive outcome. They need to be convinced that their work potential is adequate.

Studies that have looked at RTW after physical health complaints, such as musculoskeletal disorders, respiratory problems, and cardiovascular problems, suggest that demographic factors (age, gender, tenure) were not clearly associated with probability of work resumption. ${ }^{31,32}$ Therefore 


\section{Hypothesis 2:}

Demographic characteristics such as age, gender, tenure, and level of education, as well as job tenure, do not predict RTW. ${ }^{2}$

On the other hand, psychological aspects of the returnee may also have an impact on the RTW process. When people have been out of work for a long period, they need to readjust to their (new) situation. They may have to learn to cope with some functional limitations, but it may also be a "resocialization process" (getting used to the work routine again). This suggests that psychological factors do affect the RTW process, and some are hindering the reintegration. For instance, Van den Klink et $\mathrm{al}^{33}$ found that people with adjustment disorders are very unlikely to RTW. Also, in a study by Shrey and Mital, ${ }^{34}$ it appeared that a personality characteristic, or the type A personality, is also a factor that stimulates RTW, because people with type A personality are competitive and have a constant drive to improve. This drive also helps them in their revalidation process, and therefore, their personality helps them to recover and RTW more quickly than others.

Studies that have looked at RTW after physical health complaints, such as musculoskeletal disorders, respiratory problems and cardiovascular problems, suggest that demographic factors (age, gender, tenure) are not clearly associated with work resumption. ${ }^{31,32}$. However, a person's level of self-efficacy might also play a role. Self-efficacy refers to a person's feeling of competence and ability, either in a particular domain or in general. ${ }^{35,36}$ Self-efficacy has been mentioned in the literature as playing an important role in the RTW process. ${ }^{37}$ Nevertheless, a recent longitudinal study by Labriola et $\mathrm{al}^{5}$ directed at empirically exploring the impact of self-efficacy on RTW in a large sample of Danish workers did not find the expected relationship.

Self-efficacy is based on the persons appraisal of their present condition and the confidence to perform a set of specific activities. ${ }^{34}$ When people feel confident about their health and their skills, one could presume that this makes it easier to RTW again, whereas lack of confidence, ie, a low level of self-efficacy, will make this more complicated.

Therefore, it can be expected that peoples' appraisal of their own situation influences the RTW process in the interplay of the employment situation, the medical care process, and the individual worker's health and personal characteristics. ${ }^{38}$ Previous work has not registered a significant correlation between self-efficacy before the absence and subsequent RTW. ${ }^{5}$ Nevertheless, in this study, the joint effects of the other intervening variables was not considered. Furthermore, a three-item measure derived from the original scale was used instead of the more comprehensive 10-item scale.

In the same vein, one could argue that depressive feelings will prevent people from returning to work. ${ }^{39}$ Depressive feelings are associated with low levels of self-efficacy, and thus we expect that feelings of depression are negatively associated with RTW. Thus, despite a gap in the literature in this area, one could argue that other psychological factors will influence RTW. Examples of these factors are the relative importance that work has in a person's life. The more central the role of work in a person's life, the more important RTW will be for this person and, thus, the better the chances for RTW. ${ }^{40}$ Hence, when people think that work is very important in their life, ie, work plays a central role in their life, it is also likely that people will make more efforts to RTW.

\section{Hypothesis 3:}

Individual characteristics, such as self-efficacy, depressive feelings, work centrality, and life events are positively related to $\mathrm{RTW}^{2}$

This means that a high level of self-efficacy and work centrality, and a low level of feelings of depression and life events are correlated with higher likelihood to resume work.
As stated above, people evaluate and reflect on their own situation, and they also assess the situation at work. This means that the success of RTW programs is not only dependent on the presence of objective factors, like whether the organization has a "return to work policy" in place or whether people have access to an occupational health physician, etc, but also the person's assessment of the situation needs to be taken into account. This applies to the organization as well. For instance, although a supervisor intends to be supportive, this doesn't automatically mean that the returnee will appreciate or notice the work the supervisor may have done behind the screens to facilitate the process of returning to work. This means that, primarily, the perceived support is important here.

A few studies consider organizational aspects that affect the process of work resumption. In particular, supervisor behavior is seen as crucial for successful RTW. Supportive behavior of the supervisor, and also colleagues, makes RTW much easier. ${ }^{30}$ Nieuwenhuijzen et al ${ }^{30}$ also demonstrated that in organizations were the success rate for RTW was higher, supervisors communicated more frequently and better with other RTW professionals. Supervisor's behavior and support before absence was also found to be a good predictor for successful RTW, ${ }^{41}$ and social support in the workplace enhances the chance of successful RTW in a sample of absentees with musculoskeletal problems. ${ }^{42}$ In particular, when colleagues were made aware of the limitations of the returnee, this helped to overcome frictions as a consequence of perceived unjustified favoritism. Thus, a supportive behavior of supervisors and colleagues is likely to enhance RTW.

In general it appears that when organizations are motivated to retain their personnel, they have more successful cases of work resumption. ${ }^{43}$ This stimulation can take the form of legal provisions to have a certain percentage of disabled people among the staff, financial incentives to employ people with disabilities, or punishment when contracts of people with disabilities are terminated. The consequences of these arrangements are that organizations are more willing to make adjustments when necessary and to think about what is required to help the absentee to RTW. This might lead to what can be called a favorable attitude toward RTW, which is accompanied by installing procedures and practices that are beneficial for RTW. In this perspective, work resumption is not only an individual human factor but also evidently a matter of social and organizational context. This perspective is critically important for RTW, because the context assume importance in the design and development of organizational practices, policies, and procedures, which help to retain the workforce and also favor the RTW after a short of long spell of absence because of either mental or physical ill health.

Thus, we can expect that organizational policies focusing on retaining personnel will have a positive effect on RTW. In particular, when such policies are in place before absence has started, it signals a general concern for the well-being of the employees in the organization. Thus, as also better specified below, organizational policies focusing on prevention will be more effective than policies focusing that have been installed after the period of absence (and are thus more geared toward RTW).

The ensemble of organizational policies, practices, and procedures recognized in a specific organizational context are usually referred to as organizational climate. ${ }^{44,45}$. More specifically, the term organizational climate indicates the shared appraisal of employees of the organizational policies, practices, and procedures. These can be strategic, eg, safety, service delivery, and so on, ${ }^{46-50}$ or more general. ${ }^{45,51}$ With respect to the topic at hand, it is important to know whether there is a particular climate with respect to RTW in the organization. Climate does affect employees' behavior, 52 and the behavior of employees is crucial for the success of 
a RTW process. These factors are all meant to strengthen an individual's belief that RTW can be successful (TRA ${ }^{28}$ ). Thus

\section{Hypothesis 4:}

Organizational aspects, such as specific arrangements for work resumption during and after the spell of absence, together with the appraisal of the work environment-supervisor and colleagues' support-are positively related to RTW. ${ }^{2}$

Organizational policies are important to judge an organization's concern with their staff. Nevertheless, general policies aim at a broad spectrum of problems, whereas more specific measures are needed sometimes. However, organizations can not always foresee what kind of problems may arise. Thus, measures taken after the person becomes absen, are generally more geared toward the specific case and may, therefore, be more beneficial for RTW than policies that were already in place. We, therefore, hypothesize that:

\section{Hypothesis 5:}

Organizational policies and arrangements that are in place before the spell of absence started will be less effective than policies and arrangements that were installed after the spell of absence started. ${ }^{2}$

This study is a European study, conducted in six European countries. And, apart from individual believes about health situation and organization's efforts to help people to RTW, there are also large differences between various countries with respect to the social security systems and national policies on this topic. Some countries (ie, the Netherlands, Finland) have a strong focus on RTW in their national policies (ie, the so-called Act gatekeeper in the Netherlands; www.arbo-advies.nl). This means that one can expect a "country effect" as well. Evidently, the social security system also affects the level of income that an absentee receives. Nevertheless, our study was not aimed at evaluating social security systems; we, therefore, do not formulate specific hypotheses concerning this aspect.

There is no literature available focusing on the differences between people with PHs and MHs and the factors contributing to RTW. Therefore, it is difficult to formulate clear predictions based on previous research. Nevertheless, since mental health conditions are now responsible for a large part of all sickness absence, we include an exploratory analysis in which we compare the contribution of the above factors for RTW for both groups. Our expectation was, nevertheless, that "soft factors" (ie, supervisor support, organizations' concern for employees' well-being) are more important for RTW for people with MHs than for people with PHs.

\section{MATERIALS AND METHODS}

\section{Participants}

RTW is a focal point of the political discussion in the EU, we, therefore, tested these hypotheses using a large sample of LTAs acquired from five EU countries. A large survey among people absent from work for health reasons has been conducted in five EU countries (Austria, Ireland, Finland, Netherlands, and the United Kingdom). National registries and databases of sickness absentees and social insurance agencies were contacted to collect participants for the study. This approach proved to be the best option to obtain samples that were representative for each country.

Potential respondents were contacted, and the purpose of the study was explained. Their participation was requested, confidentiality ensured, and if they agreed to participate, they could reply by returning a preaddressed answering slip. Ethical permission was obtained in each country by appropriate Medical Ethical Research Committees.

In each country, approximately 400 people absent from work for health reasons took part in the study. Inclusion criteria for the study were being in fulltime employment previous to the period of absence ( $>32$ hours per week) and having been absent for more than 8 weeks at the time of the start of study (but no longer than 6 months). Participants received a questionnaire containing questions concerning demographic characteristics (age, sex, marital status, and level of education); family situation (children, financial situation); health situation and lifestyle; aspects of current personal well-being; characteristics of job previous to absence; characteristics of the organization; and contextual aspects (availability or knowledge of help and services or both, intervention programs). Wherever available, existing scales and instruments were incorporated in the questionnaire (ie, job characteristics and aspects of personal well-being), they will be described later.

Respondents were also requested to indicate the cause of their current absence; they were instructed to indicate one of three categories: a) health complaints were primarily of physical nature; b) complaints were primarily caused by mental ill health; and c) a combination of PHs and MHs - ie, comorbidity. For the purpose of this study, respondents were excluded from the analysis if they reported a comorbid condition, because it was not always clear that which of the two conditions initiated the absenteeism and was the main reason for absence.

\section{Measures: Work Absence and RTW Questionnaire}

A complete version of the questionnaire is available from the authors. From the measures included in the questionnaire, only the variables described below were used for this study.

\section{Demographic Aspects}

Gender, age, marital status, level of education, and job tenure were assessed by the questionnaire.

\section{Psychological Factors}

\section{Perceived Health}

Respondents were asked to indicate how they would rate their health "compared with others of the same age and sex" on a 5-point scale ranging form "poor" to "excellent." Such a formulation of this question results in adequate assessments of health. ${ }^{53}$ The same question was asked at the second measurement, and in addition, it was asked whether people felt that their health had changed (and in what direction). In the analysis, we used peoples' ratings of their general health both at time 1 and time 2 .

\section{Well-Being}

As indicators of well-being, we used measures of selfefficacy, emotional exhaustion, feelings of depression, and life events.

Self-Efficacy. For perceived levels of self-efficacy, the General Self-efficacy 10 items scale was used. ${ }^{54}$ Responses were on a Likert-type scale, categories ranging from 1 "not at all true" to 5 "exactly true" (sample: I can always manage to solve difficult problems if I try hard enough). Cronbach $\alpha$ for the sample was 0.92 .

Emotional Exhaustion. The Oldenburg Burnout Inventory ${ }^{55}$ was used. This scale contains eight items. Items are measured with a 4-point Likert scale, categories ranging from "always" to "never" (sample question: I always find new and interesting aspects in my work). Cronbach $\alpha$ for the sample was 0.84 .

Feelings of Depression. Depression has been measured with the CES-D. ${ }^{56,57}$ A 10-item version was used; items are expressed on a 4-point Likert scale from "rarely" to "all the time" (sample question: I feel bothered by things that usually don't bother me; $\alpha=0.94$ ).

Life Events. Respondents were asked whether there had been any occurrences in the last 3 months that caused them stress. Similar to Holmes and Rahe, ${ }^{58}$ a list of topics was presented concerning family, friends, relationships, work, and financial situation $(\alpha=0.80)$. 


\section{Psychosocial Aspects of the Job}

\section{Job Stress}

To assess the psychosocial characteristics of the jobs we used five scales. The first four came from the Job Demand/Control Support questionnaire $\left.{ }^{59}: 1\right)$ demands (4 items); 2) job control (7 items); 3) coworker support; and 4) supervisor support (4 items each; example item: "My supervisor/colleague is helpful in getting the job done"; Cronbach $\alpha$ are 0.77, 0.90, 0.90, and 0.78, respectively). A fifth scale, reward (8 items), was taken from Siegrist's Effort-Reward model. ${ }^{60}$ All items should be answered on a 4-point Likert scale, with $1=$ "strongly disagree" and $4=$ "strongly agree" (example item: My job requires me to work very fast; $\alpha=0.62$ ).

\section{Stress}

Stress was assessed with the single item technique ${ }^{61}$, as applied by Elo et al. ${ }^{62,63}$ First, a description was given of what is stress, and then, respondents were instructed that: "Indicate on a scale from 1 to 10 how much stress you experienced in the last months."

\section{Work Ability}

The Work ability Index ${ }^{64,65}$ was used to measure work ability. Three single items were used to measure work ability: general work ability, mental work ability (how would you rate your current ability to work with respect to the mental demands of your work), and physical work ability (how would you rate your current ability to work with respect to the physical demands of your work).

General work ability is measured on a continuum from 1 to 10 (from completely unable to work to work ability at its best); mental work ability and physical work ability are presented on a 5-point Likert scale ranging from "very poor" to "very good." Work ability at T2 was measured with the same scale.

\section{Work Centrality}

Work centrality refers to the extent peoples' goals in life are related to work, and thus, how central (how important) work is in life. ${ }^{40}$ This aspect was measured with a single question to be answered on a 5 -point scale. ${ }^{66}$

\section{Organizational Policies for Work Resumption}

The concept of work resumption policies was assessed by the combination of five items asking about specific organizational policies facilitating work resumption: a) are there any RTW policies in your organization? (no, yes); b) is there a specific person in your organization who is responsible for the coordination of your work resumption? (no, yes, don't know); c) has your organization made any kind of work arrangements before you became absent? (no, yes); d) has your organization made any kind of work arrangements after you became absent? (no, yes); and e) did you participate in any staff counseling/support program? (no, yes). When organizational policies/arrangements are in place before the person became absent, this is believed to demonstrate a general concern of the organization for employees' well-being. Arrangements made after absence are primarily focused on RTW for that individual.

In addition, we asked for respondents' experiences during their absence.

\section{Experiences During the Period of Absence}

A set of questions were asked focusing on how people experienced the period of absence. Example questions were as follows: "I missed my work"; "I felt guilty for not being at work;" "It gave me an opportunity to consider the importance of things in life;" and "It gave me the chance to detach myself from work" $(\alpha=0.69)$.

Furthermore questions were asked (in particular, in the second wave questionnaire) whether people had changed (yes/no) several habits and aspects of their lifestyle (such as sports, physical, and social activities, sleeping pattern, smoking habits and alcohol consumption, and so on). The answers to these questions were summed up, so that they could form a scale indicating "changes in lifestyle" as a result of being absent.

\section{Return to Work}

As in previous studies, ${ }^{5}$ also in this study, RTW was defined as the cessation of sickness absence benefit or any other social transfer benefit. Respondents were asked whether they had a) returned to work completely; b) returned to work partially or on a therapeutic basis; and c) not returned to work. According to Nieuwenhuijsen et al, ${ }^{30}$ full RTW meant return and working the same number of hours as before the sickness absence. Partial RTW was operationalized as a first RTW, but with a reduced number of hours per week.

This question was asked at time 1 (first measurement wave) and time 2 (second measurement wave: 6 months later). When respondents had already returned to work at $\mathrm{T} 1$, they were left out of the analysis (this concerned only very few respondents).

\section{Research Design}

To be able to note changes or developments over time, eg, attitudes to work resumption, improvement or decline in health status, with a time lag of 6 months, a second questionnaire was sent to all those who participated in time 1 of the research study. In total, 2002 questionnaires have been returned in the first wave. In the second wave, $73 \%$ of the initial sample (1460) returned their questionnaire. For a detailed overview of the characteristics of the respondents in the sample see Table 1.

\section{Data Analysis}

The hypotheses have been tested with logistic regression analysis, which allows calculating odds ratios. The odds ratio is an indicator of the predictability of the presence or absence of a particular characteristic based on values of a set of predictor variables. "Work resumption" was used as the criterion in the analysis. In general terms, the odds ratio indicates how much more chance there is that a person with a particular characteristic will RTW compared with a reference group. ${ }^{67}$

\section{RESULTS}

Characteristics of the sample are presented in Table 1. Analysis have demonstrated that both at time 1 and at time 2, there was a substantial overlap in responses between workers who had partially and fully returned to work, therefore, the three categories have been collapsed in two: a) returned to work; and b) not returned to work.

From the second measurement wave, it shows how participants who had had a spell of LTA because of a physical illness, $61 \%$ were still absent at T2 and 39\% had returned to work. As for the participants with a mental illness, $54 \%$ were still absent at T2 and $46 \%$ had resumed working.

Table 2 presents the first-order correlations among the variables. Our first hypothesis predicted that when people perceive improvement of their health, this will lead to more people returning to work. We, therefore, compared two groups: a) those who reported that their health had improved from $\mathrm{T} 1$ to $\mathrm{T} 2$, and $\mathrm{b}$ ) those who reported no improvement of health between T1 and T2.

First results demonstrate that of all respondents who returned the second questionnaire (1460), 363 people rated their health at T2 to be worse compared with T1 (6 months earlier), 683 respondents rated their health being the same, and 459 respondents rated their health to be better at T2 compared with T1 (Table 3 ).

From Table 3, it is clear that from the group "improved health," a higher percentage has returned to work at T2 when compared with group with "poorer health" (55\% vs $23 \%)$. In the 
TABLE 1. Characteristics of Respondents $(N=1,460)$

\begin{tabular}{|c|c|}
\hline & Frequency $(\%)$ \\
\hline \multicolumn{2}{|l|}{ Gender } \\
\hline Male & 48.7 \\
\hline Female & 51.3 \\
\hline \multicolumn{2}{|l|}{ Age (yr) } \\
\hline$\leq 35$ & 14.4 \\
\hline $36-45$ & 23.1 \\
\hline $46-55$ & 35.3 \\
\hline$\geq 55$ & 27.1 \\
\hline \multicolumn{2}{|l|}{ Education } \\
\hline Up to lower professional education & 32.6 \\
\hline Intermediate general and professional education & 32.2 \\
\hline Completed high school & 10.4 \\
\hline Higher professional education & 17.5 \\
\hline Academic education and higher & 7.3 \\
\hline \multicolumn{2}{|l|}{ Marital status } \\
\hline Married & 59.4 \\
\hline Cohabiting & 9.3 \\
\hline Single & 15.1 \\
\hline Divorced & 13.9 \\
\hline Widowed & 2.3 \\
\hline \multicolumn{2}{|l|}{ Job title } \\
\hline Legislators, senior officials, and managers & 7.6 \\
\hline Professionals & 12.7 \\
\hline Technicians and associate professionals & 9.3 \\
\hline Clerks & 13.9 \\
\hline $\begin{array}{l}\text { Service workers and shop and market sales } \\
\text { workers }\end{array}$ & 17.3 \\
\hline Skilled agricultural and fishery workers & 1.2 \\
\hline Craft and related trades workers & 13.9 \\
\hline Plant and machine operators and assemblers & 12.2 \\
\hline Elementary occupations & 11.8 \\
\hline \multicolumn{2}{|l|}{ Work sector } \\
\hline Agriculture & 2.5 \\
\hline Manufacturing & 16.8 \\
\hline Building & 10.5 \\
\hline Trade & 13.4 \\
\hline Hotels and restaurants & 6.1 \\
\hline Transport & 9.7 \\
\hline Banking & 4.4 \\
\hline Public administration & 6.5 \\
\hline Education & 7.3 \\
\hline Health & 14.4 \\
\hline Other community & 6.5 \\
\hline Recreational & 2.0 \\
\hline \multicolumn{2}{|l|}{ Job tenure $(\mathrm{yr})$} \\
\hline $0-5$ & 5.7 \\
\hline $6-10$ & 7.4 \\
\hline $11-20$ & 20.7 \\
\hline $21-30$ & 27.7 \\
\hline 31 and higher & 38.7 \\
\hline \multicolumn{2}{|l|}{ Job type } \\
\hline Permanent & 87.9 \\
\hline Temporary & 12.1 \\
\hline \multicolumn{2}{|l|}{ Multiple income? } \\
\hline Yes & 59.7 \\
\hline No & 40.3 \\
\hline
\end{tabular}

Children at home

Yes

30.7

No

69.3

Reason for absence

Mental

16.1

Physical

63.5

Comorbid

20.4

improved health group, people were more often absent for mental health reasons, whereas in the poor health group, the percentage of PHs was higher. This suggests that there is a better chance to perceive and report an improvement in the health condition when the absence is granted for MHs compared with PHs. Also, in the poor health condition, more often, comorbidity was found (ie, having both MHs and PHs; Table 4).

It is clear that people with poorer health give higher stress ratings at $\mathrm{T} 2\left(\mathrm{~F}_{(2,1071)}=89.4 ; P<0.001\right)$, and people with poorer health also score significantly higher on the CES-D (which measures feelings of depression; $\left.\mathrm{F}_{(2,1071)}=132,2 ; P<0.001\right)$. They also report significantly more sleeping problems and lower levels of self-efficacy. On the other hand, people with improved health rated their general workability significantly higher than people with poorer health, and people with better health indicate that their work has a more central position in their life. These are all according to expectations.

A second step focused on determining that which factors contribute significantly to RTW (ie, hypotheses 2,3 , and 4). RTW (yes/no) is a dichotomous variable; therefore, a logistic regression analysis was required to test the hypotheses. A logistic regression analysis determines the odds ratios for groups of respondents with particular characteristics, and odds ratios indicate whether particular groups have a higher or lower chance to RTW.

In the regression analysis, five groups of variables were used to predict RTW. Variables in block 1 referred to the second hypothesis and, thus, contained demographic variables (age, gender, marital status, and job tenure). The second block of variables consisted of psychological variables (feelings of depression, selfefficacy, degree to which people think work is central in their life, and life events experienced). Block 3 consisted of organizational aspects (whether the organization has policies for RTW; support from supervisor and colleagues), and the fourth block consisted of respondent's experience of being absent (whether it changed their habits, whether they missed their work, and whether their health improved), the fifth and last block referred to the country of the respondents to check country differences (which refers to differences in social security systems). The results are presented in Table 5.

Because of missing values of various variables, only 482 respondents were included in the final analysis. In the initial block (block 0 ) of the analyses (which includes the constant in the model), just over $56 \%$ of cases could be correctly classified as either returned to work or still absent. This is just a little better than chance level (ie, $=50 \%$ ).

The first block of the analysis including the demographic variables was significant $\left(\chi^{2}=59.9 ; P<0.001\right)$. However, the goodness-of-fit of this model is rather poor, given the fact that the $-2 \log$ linear $(-2 \mathrm{LL})$ is very high $(602.4)$ and that only $16 \%$ of the variance (Nagelkerke $R^{2}=0.156$ ) is explained in the model. This is in line with earlier literature ${ }^{31,68,69}$ that demographic factors only play a marginal role in predicting RTW.

Nevertheless, the final model, presented in Table 5, could classify $84 \%$ of cases correctly, and the -2LL has dropped considerably to 389.9 (which is still quite high, indicating that still a lot of variance is not accounted for). This final model explains $58 \%$ of variance (Nagelkerke $R^{2}=0.58$ ). 
TABLE 2. Correlations

\begin{tabular}{|c|c|c|c|c|c|c|c|c|c|}
\hline & $\begin{array}{l}\text { CES-D Scale; } \\
10 \text { Items } \\
\begin{array}{c}(0=\text { not to } \\
30=\text { highly } \\
\text { depressive })\end{array}\end{array}$ & $\begin{array}{l}\text { Self-Efficacy } \\
\text { Scale; } 10 \\
\text { Items } \\
(10=\text { low to } \\
40=\text { high })\end{array}$ & $\begin{array}{l}\text { Work Centrality } \\
\text { Scale; } 2 \text { Items } \\
(1=\text { not central } \\
\text { to } 5=\text { highly } \\
\text { central })\end{array}$ & $\begin{array}{l}\text { Life Events; } \\
11 \text { Items } \\
\begin{array}{c}(1=\text { low to } \\
4=\text { high })\end{array}\end{array}$ & Policies & $\begin{array}{c}\text { Coworker } \\
\text { Support }\end{array}$ & $\begin{array}{c}\text { Supervisor } \\
\text { Support }\end{array}$ & $\begin{array}{c}\text { Absence } \\
\text { Experience }\end{array}$ & $\begin{array}{l}\text { Absence } \\
\text { Perception }\end{array}$ \\
\hline $\begin{array}{l}\text { CES-D scale; } 10 \\
\text { items }(0=\text { not } \\
\text { to } 30=\text { highly } \\
\text { depressive })\end{array}$ & 1 & & & & & & & & \\
\hline $\begin{array}{l}\text { Work centrality } \\
\text { scale; } 2 \text { items } \\
(1=\text { not central } \\
\text { to } 5=\text { highly } \\
\text { central })\end{array}$ & $-0.092 * *$ & $0.194 * *$ & 1 & & & & & & \\
\hline Policies & -0.034 & 0.040 & -0.027 & -0.049 & 1 & & & & \\
\hline Coworker support & $-0.186^{* *}$ & $0.214 * *$ & $0.064 *$ & $-0.148 * *$ & $0.091 * *$ & 1 & & & \\
\hline Supervisor support & $-0.169 * *$ & $0.188^{* *}$ & 0.036 & $-0.161 * *$ & $0.187 * *$ & $0.406^{* *}$ & 1 & & \\
\hline Absence experience & $-0.118^{* *}$ & 0.039 & $0.069^{*}$ & $-0.096^{* *}$ & -0.006 & $-0.074^{*}$ & -0.048 & 1 & \\
\hline Absence perception & $0.150 * *$ & -0.025 & $0.076 * *$ & $0.182 * *$ & $0.060 *$ & -0.021 & -0.019 & $-0.068^{*}$ & 1 \\
\hline
\end{tabular}

TABLE 3. Comparison of Respondents With Poorer vs Better Health at T2

\begin{tabular}{lcc}
\hline Variable & $\begin{array}{c}\text { Poorer Health } \\
(\boldsymbol{N}=\mathbf{3 6 3})(\%)\end{array}$ & $\begin{array}{c}\text { Improved health } \\
(\boldsymbol{N}=\mathbf{4 5 9 )}(\boldsymbol{\%})\end{array}$ \\
\hline Returned to work (partially/fully) & 22.9 & 54.9 \\
Still absent & 77.1 & 45.1 \\
Physical health problems & 60.1 & 55.7 \\
Mental health problems & 14.0 & 23.6 \\
Comorbidity & 25.6 & 20.6 \\
\hline
\end{tabular}

According to the final model, demographic variables have a marginally significant contribution in predicting RTW (see Table 5). Although the contribution of the variable age groups is not significant, it appears that the age group 36 to 45 years has a positive $\beta$-weight. This means that belonging to that age group has a positive influence on the odds to RTW compared with the other groups. Furthermore, it is clear that level of education has a marginally significant contribution $(P=0.06)$, and this is caused by the group "up to lower professional" educated. Being a member of this group has a negative influence on the odds to RTW $(\beta$ weight $=-1.2$ ).

According to this model, having depressive feelings at time 2 does have a significant contribution. The $\beta$-weight is negative, indicating that the more depressive feelings the smaller the odds to RTW. Work centrality also has a significant contribution: the more important work is in a person's life, the better the odds to RTW. Also, life events have a negative influence: the more (stressful) life events a person has experienced the smaller the odds that this person will RTW. This can be seen as generally supporting hypothesis 3 .

As far as the third block (organizational policy variables) is concerned, it appears that the variance explained by the variables in the block increases from $40 \%$ to $45 \%$. When the organization is prepared to make arrangements that might help to RTW (or stay in work) before the person actually becomes absent, this has a negative influence on the odds to RTW meaning that the person is less likely to resume work. Nevertheless, when arrangements are made after having become absent (which are usually part of the process to RTW), a positive $\beta$-weight is found for organizational policies ( $\beta$ weight $=0.20$ ), indicating that this has a positive effect on the odds (although the effect is not significant $P=0.08$ ). This means that hypothesis 4 is not fully supported.

The country variable had a highly significant effect, suggesting that the social security and legal system of countries has a great influence on the odds to RTW. In particular, the Dutch system seems to be responsible for this effect $(\beta$ weight $=2.07$ ); being an absentee in The Netherlands has the largest positive effect on the odds to RTW of all countries, compared with the reference category (United Kingdom).

Finally, "being able to make a living" had a negative $\beta$ weight $(-1.11)$ for the group that indicated that they could make a living without returning to work, indicating that this has a negative effect on the odds to RTW. This means that people who cannot make a living are more likely to RTW than people who can make a living. It is worth noting that the goodness of fit of the model evenly improved in each step of the logistic regression analysis.

\section{Comparison of Mental Health and Physical Health}

A similar analysis was repeated, but then separately for the group with MHs and PHs. These groups were evidently much smaller and, thus, allowing lesser variables to be included in the model. For that reason, the last block (country) was omitted from this analysis. Because of missing variables, only 101 respondents were included in the analysis in the mental health group versus 288 in the physical health group. The results for the group with PHs are presented in Table 6; and for the mental health group (MH) in Table 7. 
TABLE 4. Mean Scores of Groups With Improved Health, Same Health, and Poorer Health

\begin{tabular}{|c|c|c|c|c|c|c|}
\hline & Health & Mean & SD & $\boldsymbol{N}$ & Frequency & $P$ \\
\hline \multirow[t]{3}{*}{ Stress } & Better & 2.40 & 1.07 & 398 & 89.359 & 0.000 \\
\hline & Same & 2.49 & 1.14 & 366 & & \\
\hline & Poorer & 3.39 & 1.29 & 310 & & \\
\hline \multirow[t]{3}{*}{ CES-D scale } & Better & 8.00 & 5.54 & 398 & 132.243 & 0.000 \\
\hline & Same & 8.77 & 5.97 & 366 & & \\
\hline & Poorer & 14.28 & 6.96 & 310 & & \\
\hline \multirow[t]{3}{*}{ Self-efficacy scale } & Better & 29.62 & 5.56 & 398 & 31.348 & 0.000 \\
\hline & Same & 29.14 & 5.37 & 366 & & \\
\hline & Poorer & 26.54 & 6.64 & 310 & & \\
\hline \multirow[t]{3}{*}{ Sleeping problems } & Better & 2.01 & 0.65 & 398 & 69.632 & 0.000 \\
\hline & Same & 2.16 & 0.68 & 366 & & \\
\hline & Poorer & 2.56 & 0.70 & 310 & & \\
\hline \multirow[t]{3}{*}{ Work centrality scale } & Better & 3.03 & 1.00 & 398 & 10.638 & 0.000 \\
\hline & Same & 2.71 & 1.06 & 366 & & \\
\hline & Poorer & 2.73 & 1.11 & 310 & & \\
\hline \multirow[t]{3}{*}{ Work ability } & Better & 4.51 & 2.45 & 398 & 115.074 & 0.000 \\
\hline & Same & 4.03 & 2.35 & 366 & & \\
\hline & Poorer & 3.48 & 2.16 & 310 & & \\
\hline
\end{tabular}

When the results of both analyses are compared, it appears that the regression model for the group with MHs fits the data much better than for the group with PHs. The -2LL for $\mathrm{MH}$ is 48.8, while the $-2 \mathrm{LL}$ for $\mathrm{PH}$ is 305.1 (the lower the value of $-2 \mathrm{LL}$ the better the model fits the data. The MH-model does explain $77 \%$ of the variance (Nagelkerke $R^{2}=0.77$ ); while for the PH model Nagelkerke $R^{2}=0.37$ (thus explaining only $37 \%$ of the variance). For the PH group, $74 \%$ of cases were correctly classified in this model, whereas for the MH group, this was $91 \%$.

Gender was not significant in predicting RTW in both groups. In both groups, $\mathrm{PH}$ and $\mathrm{MH}$, age did have a significant contribution in predicting RTW (positive $\beta$-weight's); belonging to the youngest age group had a large positive impact on the odds to RTW (meaning that it influenced the odds to RTW positively).

Marital status and job tenure did not have a significant contribution in both groups. Depressive feelings, in both groups, had a significant (negative) contribution in predicting RTW; but the effect was much more pronounced in the mental health group. In the physical health group, the effect was only marginally significant. Work centrality had a strong positive contribution in the physical health group only. Work centrality refers to how important people think work is in their life.

In the group with physical health complaints, the individual's level of self-efficacy appears to have a (marginally) significant positive contribution. Higher levels of self-efficacy have a positive effect on the odds to RTW.

For the mental health group, it is interesting to see that perceived support from the supervisor has a significant positive contribution in predicting RTW. When absentees perceive their supervisor to be supportive, this has a positive influence on the odds to RTW. This seems to play hardly a role for people with PHs; in those cases self-efficacy is more important.

Organizational policies did not have a significant contribution in predicting RTW in both groups, although it did have an effect when both groups were combined. Being detached from work has a significant negative influence on the odds to RTW, again for people with physical health complaints. This is in line with the finding concerning work centrality, which also applied to people with PHs only. For people with MHs, there is no significant contribution for detachment from work.

\section{DISCUSSION}

The now longstanding recognition that being out of work is both an individual and societal problem in industrialized countries has not been accompanied by a corresponding growth in the understanding of how to modify the psychological and organizational environment in ways that will enhance the rate of work resumption, or RTW, after a long spell of absence. Research has primarily focused on sickness absence from work rather than on work resumption. In particular, previous research neglected work resumption for those cases that were caused by stress-related MHs; this last group now takes up about one third of all long-term absenteeism. The costs of work absence may be very large both in term of psychological distress in the affected workers and financially for the organization. ${ }^{70}$

The aim of this study was to fill part of the knowledge gap with respect to RTW after long-term absenteeism and embracing a European perspective. We were particularly interested in testing the hypothesis that improvement of health is a necessary, but in itself insufficient requirement for RTW. We believe that both psychological aspects and organizational aspects play an important role. Our study is based on a longitudinal survey of LTAs in five different EU-countries. The results of our study confirm our primary hypothesis. In the group with improved health, a much higher percentage of respondents have returned to work. Nevertheless, there were also a substantial percentage of people who indicated that their health had gotten worse over the period and still had returned to work. Nevertheless, within the group who had indicated that their health had improved still a fairly high percentage (45.1\%) was still absent. People in the improved health condition rated their workability as quite high and significantly better than those whose health had stayed the same or gotten worse. People in the improved health group generally feel very capable of working. This notion is in line with the TRA $^{27}$ that states the people's believes and awareness are the primary determinants of subsequent actions (actual behavior), ie, RTW. This 
TABLE 5. Results of Logistic Regression: Predicting RTW

\begin{tabular}{|c|c|c|c|c|c|c|}
\hline$N=482$ & $\boldsymbol{\beta}$ & SE & Wald & $d f$ & $P$ & $\operatorname{Exp}(\beta)$ \\
\hline Gender (male) & -0.368 & .298 & 1.526 & 1 & 0.217 & 1.445 \\
\hline Age (yr) & & & 5.620 & 3 & 0.132 & \\
\hline$\geq 35$ & 0.594 & 0.678 & 0.769 & 1 & 0.380 & 0.552 \\
\hline $36-45$ & 1.186 & 0.545 & 4.740 & 1 & 0.029 & 0.305 \\
\hline $46-55$ & 0.434 & 0.391 & 1.236 & 1 & 0.266 & 0.648 \\
\hline Marital status & & & 2.529 & 4 & 0.639 & \\
\hline Married & -0.460 & 0.980 & 0.221 & 1 & 0.638 & 1.585 \\
\hline Cohabiting & -0.818 & 1.064 & 0.591 & 1 & 0.442 & 2.266 \\
\hline Single & -1.025 & 1.075 & 0.910 & 1 & 0.340 & 2.787 \\
\hline Divorced & -0.945 & 1.048 & 0.813 & 1 & 0.367 & 2.572 \\
\hline Job tenure $(\mathrm{yr})$ & & & 0.036 & 2 & 0.982 & \\
\hline $0-20$ & -0.070 & 0.522 & 0.018 & 1 & 0.893 & 1.073 \\
\hline $21-30$ & 0.006 & 0.406 & 0.000 & 1 & 0.988 & 0.994 \\
\hline Education level & & & 9.111 & 4 & 0.058 & \\
\hline Up to lower professional & -1.240 & 0.621 & 3.990 & 1 & 0.046 & 3.455 \\
\hline Intermediate general and professional & -1.028 & 0.625 & 2.707 & 1 & 0.100 & 2.796 \\
\hline High school & -0.469 & 0.705 & 0.442 & 1 & 0.506 & 1.598 \\
\hline Academic & -0.253 & 0.624 & 0.165 & 1 & 0.685 & 1.288 \\
\hline Depressive feelings $\mathrm{T} 2$ & -0.101 & 0.031 & 10.611 & 1 & 0.001 & 1.107 \\
\hline Self efficacy T2 & -0.003 & 0.029 & 0.009 & 1 & 0.923 & 1.003 \\
\hline Work centrality $\mathrm{T} 2$ & 0.713 & 0.152 & 21.851 & 1 & 0.000 & 0.490 \\
\hline Life events & -0.695 & 0.356 & 3.801 & 1 & 0.051 & 2.004 \\
\hline Policy presence & 0.056 & 0.071 & 0.627 & 1 & 0.429 & 0.945 \\
\hline Arrangement before absence & -0.263 & 0.117 & 5.078 & 1 & 0.024 & 1.300 \\
\hline Arrangement after absence & 0.204 & 0.119 & 2.952 & 1 & 0.086 & 0.815 \\
\hline Colleague support & -0.309 & 0.282 & 1.198 & 1 & 0.274 & 1.362 \\
\hline Supervisor support & 0.051 & 0.192 & 0.070 & 1 & 0.791 & 0.950 \\
\hline Changes life style & -0.304 & 0.352 & 0.746 & 1 & 0.388 & 1.355 \\
\hline Detached from work & -0.116 & 0.242 & 0.230 & 1 & 0.632 & 1.123 \\
\hline Country & & & 40.647 & 4 & 0.000 & \\
\hline Austria & 0.284 & 0.565 & 0.253 & 1 & 0.615 & 0.753 \\
\hline Finland & -0.053 & 0.455 & 0.014 & 1 & 0.907 & 1.055 \\
\hline Ireland & 0.778 & 0.824 & 0.890 & 1 & 0.346 & 0.459 \\
\hline Netherlands & 2.068 & 0.426 & 23.604 & 1 & 0.000 & 0.126 \\
\hline \multirow[t]{2}{*}{ Can make a living (yes) } & -1.107 & 0.318 & 12.131 & 1 & 0.000 & 3.026 \\
\hline & -2.547 & 2.201 & 1.339 & 1 & 0.247 & 0.078 \\
\hline
\end{tabular}

also confirms our primary hypothesis that improvement of health is important, but not the only factor determining RTW.

The subsequent logistic regression analyses demonstrated that demographic variables play only a marginal role in predicting RTW. This confirms earlier findings of Burdorf et al. ${ }^{31}$ Important predictors appear to be respondents' level of subjective well-being (as indicated by feelings of depression-CES-D score) and how important people think their work is (work centrality). Feelings of depression are clearly associated with peoples' health situation (see before). When work is very central in a person's life, the odds to RTW appear to improve significantly. Centrality of work can be seen as an internal drive (motivation) to RTW. In this respect, this finding has similarity with findings by Shrey et al, ${ }^{34}$ who found that people with type A personality recovered more quickly from coronary heart problems.

Self-efficacy is often mentioned as another important factor for work resumption. ${ }^{36}$ Indeed, the persons feeling of competence and ability, and the confidence in their ability to perform work roles, prompted participants to resume work and provide a different scenario compared with Labriola et al. ${ }^{5}$
Self-efficacy has clearly demonstrated its role in RTW after PHs, in particular when skills are important for the job (cf. ${ }^{71}$ ). However, in our study, we measured various psychological variables, including feelings of depression. Self-efficacy and feelings of depression are strongly correlated $(-0.57)$, and it is likely that feelings of depression masked the effects of selfefficacy in our study.

The results in Table 5 also reveal that organizational policies have an impact on the odds to RTW. When the organization is prepared to make arrangements before the period of absenteeism, this affects the odds to return negatively. This could suggest that there was a general willingness in the organization to do something about the situation (maybe because it was indeed not optimal). Also, there are no indications that these arrangements were specifically helpful for the absentee. On the other hand, when arrangements are made after absenteeism, a positive effect on the odds to RTW could be noted. This may reflect that these arrangements were more specifically geared toward helping the absentee to RTW and probably part of the return process. These findings are supporting our hypotheses that people's perceptions about their context (orga- 
TABLE 6. Predicting RTW for Group With Physical Health Problems

\begin{tabular}{|c|c|c|c|c|c|c|}
\hline$N=288$ & $\boldsymbol{\beta}$ & SE & Wald & $d f$ & $P$ & $\operatorname{Exp}(\beta)$ \\
\hline Gender (male) & 0.124 & 0.324 & .146 & 1 & 0.702 & 0.883 \\
\hline Age (yr) & & & 6.230 & 3 & 0.101 & \\
\hline$\geq 35$ & 1.362 & 0.742 & 3.372 & 1 & 0.066 & 0.256 \\
\hline $36-45$ & 1.461 & 0.592 & 6.088 & 1 & 0.014 & 0.232 \\
\hline $46-55$ & 0.680 & 0.407 & 2.787 & 1 & 0.095 & 0.507 \\
\hline Marital status & & & 7.507 & 4 & 0.111 & \\
\hline Married & -0.647 & 1.193 & 0.295 & 1 & 0.587 & 1.911 \\
\hline Cohabiting & -1.419 & 1.276 & 1.238 & 1 & 0.266 & 4.135 \\
\hline Single & -1.483 & 1.305 & 1.290 & 1 & 0.256 & 4.405 \\
\hline Divorced & -1.968 & 1.324 & 2.209 & 1 & 0.137 & 7.155 \\
\hline Job tenure $(\mathrm{yr})$ & & & 2.037 & 2 & 0.361 & \\
\hline $0-20$ & 0.606 & 0.554 & 1.194 & 1 & 0.275 & 0.546 \\
\hline $21-30$ & -0.026 & 0.455 & 0.003 & 1 & 0.955 & 1.026 \\
\hline Education level & & & 4.275 & 4 & 0.370 & \\
\hline Up to lower professional & -0.603 & 0.838 & 0.518 & 1 & 0.472 & 1.828 \\
\hline Intermediate general and professional & -0.374 & 0.821 & 0.207 & 1 & 0.649 & 1.453 \\
\hline High school & -0.359 & 0.910 & 0.156 & 1 & 0.693 & 1.432 \\
\hline Academic & 0.261 & 0.855 & 0.093 & 1 & 0.760 & 0.770 \\
\hline Depressive feelings $\mathrm{T} 2$ & -0.071 & 0.038 & 3.496 & 1 & 0.062 & 1.074 \\
\hline Self efficacy $\mathrm{T} 2$ & 0.063 & 0.034 & 3.398 & 1 & 0.065 & 0.939 \\
\hline Work centrality $\mathrm{T} 2$ & 0.676 & 0.163 & 17.117 & 1 & 0.000 & 0.509 \\
\hline Life events & -0.283 & 0.454 & 0.390 & 1 & 0.532 & 1.328 \\
\hline Policy presence & -0.050 & 0.038 & 1.715 & 1 & 0.190 & 1.051 \\
\hline Colleague support & -0.145 & 0.340 & 0.182 & 1 & 0.669 & 1.156 \\
\hline Supervisor support & 0.060 & 0.218 & 0.075 & 1 & 0.784 & 0.942 \\
\hline Changes life style & 0.302 & 0.361 & 0.701 & 1 & 0.403 & 0.739 \\
\hline \multirow[t]{2}{*}{ Detached from work } & -0.615 & 0.283 & 4.731 & 1 & 0.030 & 1.850 \\
\hline & -1.081 & 2.592 & 0.174 & 1 & 0.677 & 2.948 \\
\hline
\end{tabular}

nizational aspects) are important for their decision to RTW (hypotheses 4 and 5).

Furthermore, it appeared that the variable "country" had a significant effect on the odds to RTW. This refers to the whole legal and financial aspects of the social security system of a country. In many countries is the level of financial compensation for incapacity benefit recipients and other recipients of social security, a permanent issue for political debate. One point of view advocates that low levels of social benefits would encourage people to RTW. However, the results of the Stress Impact study suggest that a social security system that is actively focused on helping people to return is more effective than reducing the level of income. The results of this study indicate that the Dutch system has the highest percentage of returnees, however, the level of income for absentees belongs to the highest in the Netherlands.

The Dutch system clearly represents the highest odds to RTW again, compared with the other countries. As is clear from a review of the social security systems of the countries participating in this project, the Dutch system is most geared toward RTW.72 Active measures are in place to prevent absenteeism, and furthermore, the system is actively focusing on helping people to RTW. Dutch companies are responsible for their employees while they are on sick leave (ie, pay their salary), and both parties (employee and employer) are actively involved in reintegrating in the work process. And, this seems to pay off as the odds to RTW in the Netherlands is the highest of all countries. Being financially independent from work (ie, being able to make a living without work) evidently influences the odds to RTW negatively. Here it should be taken into account that the cause of the absenteeism is work related.
This means that it is quite natural that there is an aversion toward work, and in addition, returning to work may imply that one needs to overcome all kind of hindrances.

The final regression model in Table 5 actually had a rather poor fit to the data. Only $58 \%$ of the total variance could be explained by the regression model. This could be an indication that the model did not include some important predictors for RTW. Nevertheless, it can also be an indication that combining the group with PHs and the group with MHs in one model is problematic, because both groups are in fact quite different. Running the regression model for each group separately supports the latter suggestion. The regression model had a much better fit with the data (explaining $77 \%$ of the variance) when only respondents with $\mathrm{MHs}$ were included. For the group with physical health complaints, the fit was much poorer $(37 \%)$. This suggests that a different model should be used for each group. Depressive feelings appeared to have a negative impact on RTW for both groups. This is in line with expectations: depressive feelings make it difficult to cope with the demands of work.

Psychological aspects have a significant contribution in predicting whether people will RTW or not. However, different aspects (self-efficacy, centrality of work, and detached from work) were found to be important for the group with PHs than in the group with MHs (depressive feelings). People with PHs need to overcome hindrances when returning to work. A high level of self-efficacy (and self-confidence) may be helpful in overcoming the disadvantages of physical impairments. The more important work is for those people, the greater the drive, motivation to overcome this hindrances and RTW. 
TABLE 7. Predicting RTW for Group With Mental Health Problems

\begin{tabular}{|c|c|c|c|c|c|c|}
\hline$N=101$ & $\boldsymbol{\beta}$ & SE & Wald & $d f$ & $P$ & $\operatorname{Exp}(\beta)$ \\
\hline Gender (male) & 0.465 & 1.006 & 0.214 & 1 & 0.644 & 0.628 \\
\hline Age (yr) & & & 6.499 & 3 & 0.090 & \\
\hline$\geq 35$ & 7.804 & 3.347 & 5.438 & 1 & 0.020 & 0.000 \\
\hline $36-45$ & 6.667 & 2.671 & 6.231 & 1 & 0.013 & 0.001 \\
\hline $46-55$ & 2.650 & 1.685 & 2.473 & 1 & 0.116 & 0.071 \\
\hline Marital status & & & 6.914 & 4 & 0.141 & \\
\hline Married & 2.162 & 2.088 & 1.073 & 1 & 0.300 & 0.115 \\
\hline Cohabiting & 0.261 & 2.425 & 0.012 & 1 & 0.914 & 0.771 \\
\hline Single & -2.636 & 2.654 & 0.986 & 1 & 0.321 & 13.950 \\
\hline Divorced & -2.458 & 2.614 & 0.884 & 1 & 0.347 & 11.678 \\
\hline Job tenure $(\mathrm{yr})$ & & & 3.031 & 2 & 0.220 & \\
\hline $0-20$ & -3.075 & 2.198 & 1.958 & 1 & 0.162 & 21.655 \\
\hline 21-30 & -0.288 & 1.544 & 0.035 & 1 & 0.852 & 1.334 \\
\hline Education level & & & 11.011 & 4 & 0.026 & \\
\hline Up to lower professional & -5.181 & 1.964 & 6.958 & 1 & 0.008 & 177.776 \\
\hline Intermediate general and professional & -3.432 & 1.444 & 5.645 & 1 & 0.018 & 30.927 \\
\hline High school & 3.043 & 2.636 & 1.332 & 1 & 0.248 & 0.048 \\
\hline Academic & -2.322 & 1.468 & 2.501 & 1 & 0.114 & 10.191 \\
\hline Depressive feelings T2 & -0.385 & 0.123 & 9.768 & 1 & 0.002 & 1.470 \\
\hline Self efficacy T2 & -0.046 & 0.095 & 0.239 & 1 & 0.625 & 1.047 \\
\hline Work centrality $\mathrm{T} 2$ & 0.580 & 0.542 & 1.143 & 1 & 0.285 & 0.560 \\
\hline Life events & -0.860 & 1.102 & 0.609 & 1 & 0.435 & 2.363 \\
\hline Policy presence & -0.267 & 0.174 & 2.351 & 1 & 0.125 & 1.306 \\
\hline Colleague support & -1.529 & 1.036 & 2.177 & 1 & 0.140 & 4.612 \\
\hline Supervisor support & 1.552 & 0.740 & 4.394 & 1 & 0.036 & 0.212 \\
\hline Changes life style & -0.712 & 1.335 & 0.285 & 1 & 0.594 & 2.038 \\
\hline \multirow[t]{2}{*}{ Detached from work } & -0.951 & 0.897 & 1.125 & 1 & 0.289 & 2.589 \\
\hline & 10.974 & 6.646 & 2.727 & 1 & 0.099 & 0.000 \\
\hline
\end{tabular}

People with mental health complaints have different problems. People having suffered from a burnout acknowledge that centrality of work and over-commitment very often was part of the cause of their burnout. ${ }^{73,74}$ They understand that this needs to be changed, and a reorientation toward the priorities in their life is often part of the recovery process. Therefore, centrality of work doesn't play the same role for people with mental health complaints as it does for people with physical impairments.

Organizational aspects, such as work arrangements, appeared to contribute only significantly in the regression model for combined groups. The fact that it was not significant in the smaller groups may be because of a reduced number of respondents and, thus less statistical power in those models. For people with mental health complaints, the perceived support from supervisor did play a significant role: the more supportive the supervisor, the better the odds to RTW.

These findings make clear that different variables and factors play a role in the RTW process for people with MHs and PHs. To summarize, the results of this study clearly demonstrate that improvement of health is important but not sufficient for RTW. Also, psychological (ie, the appraisal of the situation: well-being; importance of work) and organizational factors (ie, policies) and the appraisal of these organizational factors (ie, supervisor support) play an important role. Moreover, it should be recognized that different variables have a differential influence in different groups of people (PHs or MHs). However, all-in-all, this study demonstrates that workers who simultaneously show recovery and positive appraisal of the context are more prone to resume working even after a long period of absence.
With respect to sickness absence Allegro et $\mathrm{al}^{2}$ have proposed a model of which the core is that the onset of absenteeism is the result of a decision-making process. Absentees have to make a decision to stay home, and making this decision is seen as taking a threshold. This decision is affected by various aspects, of which the health situation is an important one, but also work-related aspects and personal factors play a role. It seems as if a similar model holds for work resumption: people have to make the decision to go to work again, which is also like passing a threshold, in which the above mentioned variables and how they are appraised by the individual, affect the level of the threshold. This can be summarized in the following model.

This model describes RTW as a process in which factors that are objectively present (environmental and personal characteristics) are interpreted (appraised) by the absentee and, thus, form their subjective reality. This subjective reality is the basis on which people act: it forms the basis of their estimation of their workability and consequently their decision to RTW (or not).

This model's strength is that it incorporates the psychological and environmental factors, and illustrates how these factors interact to lead to a final outcome. It makes clear that RTW is not an automatic process that results from an improved health condition. Work resumption is the observable outcome of cognitive processes in which a person tries to assess whether there is a match between personal strengths and possibilities and environmental constraints and demands, facilitated by policies and procedures for work resumption.

Interaction models are not new in I/O or occupational psychology. Interaction models are quite popular in the field of work 
stress, ie, the Person-Environment Fit model ${ }^{75}$ and Siegrist's ${ }^{60}$ Effort-Reward Imbalance model, but none of these models have explicitly looked to work resumption.

\section{Strengths and Limitations}

Our results extend the knowledge from previous studies, nevertheless, some disadvantages of our approach need to be considered. The main disadvantage is that only the most severe cases were included in this study, because statistics have indicated that the longer the period of absenteeism, the slimmer the chances to RTW. From the literature, it is evident that a critical point in terms of RTW appears to be about 12 weeks of absenteeism. On the other hand, this provides a good opportunity to study those factors that are really relevant in long-term absenteeism.

Furthermore, the ethical principles of safeguarding the privacy of respondents prevented us from comparing the profiles of the respondents that opted in to this study and the ones that did not. And the study was primarily based on self-report of study participants, which implies that information is dependent on how accurately people recall this information. On the other hand, we tried to use a combination of objectively verifiable and subjective measures, as well as questionnaires, administered at different points in time - the longitudinal framework - has certainly helped to control for this disadvantage.

However, one of the undisputable strengths of this study is that it is the first that has collected data from a large sample of LTAs across five European countries, in two waves. It is a crosssectional study incorporating respondents from a variety of economic sectors and occupational professions. We assessed the groups after they had been absent for at least 8 to 10 weeks and in some countries even longer. The force of our results is strengthened by its longitudinal design across organizations and European countries. Nevertheless, further progress in this area would benefit the field.
A limitation of the existing literature is that studies were limited to a few professional sectors, such as education and services, ${ }^{30}$ or comparing specific groups of blue-collar workers, ${ }^{31}$ or blue collars compared with office workers. ${ }^{32}$ This study described here has taken a different approach: LTAs across organizations and occupational sectors were approached and questioned about their problems and options, thus, offering the LTA perspective on work resumption.

Because the study took place in five different countries, five different procedures had to be followed; different registers and databases had to be contacted to obtain the respondents for this study. This evidently has caused differences with respect to sampling techniques and incomparabilities of samples on particular characteristics. However, there was no other way to accomplish this study, and because this data set is unique in its kind, the data and results are highly valuable.

Another aspect concerns the fact that all the data are based on self-report (survey and interviews). This prohibits making causal inferences. In this study, we have collected data at two points in time, which allowed comparing data from different points in time and thus gathering information on real changes (such as in health situation) that have taken place. It is obvious that self-assessment of health is not the same as an officially diagnosed health condition, but the individuals perception of their own health may be more important for the decision to RTW than a medical diagnosis, because there was a strong correlation between perceived health status and self-assessment of workability. Yet again, it should be stressed that the uniqueness of this data set represents its greatest strengths.

\section{CONCLUSION}

There is a considerable amount of literature on psychological research on absenteeism ${ }^{76}$; the time now has come to complement

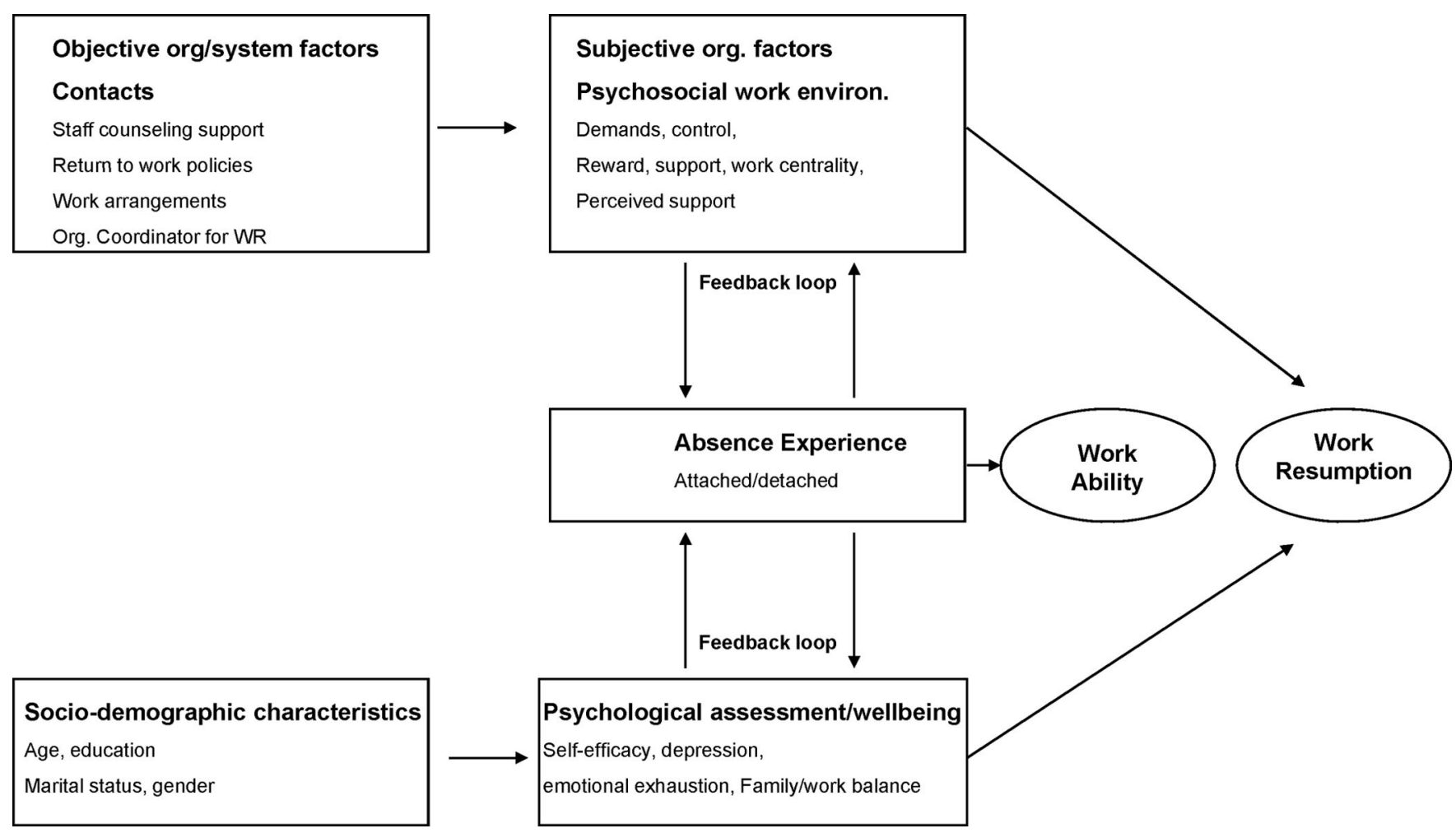

FIGURE 2. Work resumption: a model. 
this with more substantiated results on work resumption. Data on LTAs is very scarce. This study showed that health is an important factor, but not the only factor influencing the decision to RTW. Psychological and contextual factors are also important. There are different specific factors predicting RTW for people with PHs or MHs. Nevertheless, the results of this study suggest that the model of passing a threshold ${ }^{2}$ adequately describes the RTW process: both for physical and mental health complaints. People need to take a decision to RTW again. The model presented in Fig. 2 encompasses the variables that influence such a decision in a coherent framework and suggests that approaching this decision as a process is probably the best option. Single constructs cannot capture the complexity of the phenomenon. At the opposite, the combination of the factors influencing that decision can be best perceived as "push and pull" factors that help people over the threshold.

To facilitate RTW, a specific climate needs to be created that incorporates procedures and policies that are geared toward work resumption, both at the organizational and national level. The Dutch system is a good example. The Netherlands respondents had better odds to RTW compared with other countries. The Dutch system is more geared toward helping people RTW than systems in other countries. ${ }^{72}$. This systems factor clearly is an example of a push factor. And, on the other hand, when the job has been kept open for the absentee, this can work as a pull factor (provided that the job is of adequate quality).

\section{REFERENCES}

1. Schalk M. Determinanten van kortdurend ziekteverzuim. Dissertatie Katholieke Universiteit Nijmegen. Gravenhage: Delwel; 1989.

2. Allegro JT, Veerman TJ. Sickness absence. In: Drenth PJD, Thierry H, de Wolff, CJ, eds. Handbook of Work and Organizational Psychology, Vol. 2. Work Psychology. 2nd ed. Hove, East Sussex: Psychology Press; 1998:128144.

3. Voss M, Floderus B, Diderichsen F. Physical, psychosocial, and organisational factors relative to sickness absence: a study based on Sweden Post. Occup Environ Med. 2001;58:178-184.

4. Caverley N, Cunningham JB, MacGregor JN. Sickness presenteeism, sickness absenteeism, and health following restructuring in a public service organization. J Manage Stud. 2007;44:304-319.

5. Labriola M, Lund $T$, Christensen $K B$, et al. Does self-efficacy predict return-to-work after sickness absence? A prospective study among 930 employees with sickness absence for three weeks or more. Work. 2007;29: 233-238.

6. Andrea H, Beursken AJ, Metsemaker JF, van Amelsvoort LG, Kant Y, van Schayck CP. Health problems and psychosocial work environment as predictors of long term sickness absence in employees who visited the occupational physician and/or general practitioner in relation to work: a prospective study. Occup Environ Med. 2003;60:295-300.

7. Farrel D, Stam CL. Meta-analysis of the correlates of employee attendance. Hum Relat. 1988;41:211-227.

8. Kivimäki M, Kalimo R, Toppinen S. Sense of coherence as a modifier of occupational stress exposure, stress perception, and experienced strain: a study of industrial managers. Psychol Rep. 1998;83:971-981.

9. Ala-Mursula L, Vahtera J, Kivimäki M. Employee control over working times: associations with subjective health and sickness absences. J Epidemiol Community Health. 2002;56:272-278.

10. Alexanderson K, Hensing G, Leijon M. Pregnancy related sickness absence in a Swedish county, 1985-1987. J Epidemiology Community Health. 1994;48:464-470.

11. Benavides FG, Benach J, Mira M, Saez M, Barcelo A. Occupational categories and sickness absence certified as attributable to common diseases. Eur J Public Health. 2003;13:51-55.

12. Führer R, Shipley MJ, Chastang JF, et al. Socioeconomic position, health, and possible explanations: a tale of two cohorts. Am J Public Health. 2002;92:1290-1294.

13. Riksförsäkringsverket. Långtidssjukskrivningar för psykisk sjukdom och utbrändhet. 2002:4.

14. Ashworth, HW. Sickness absence and return to work. J Roy Soc Med. $1965 ; 58: 825-826$
15. Kivimaki M, Forma P, Wikstrom J, et al. Sickness absence as a risk marker of future disability pension: the 10-town study. J Epidemiol Community Health. 2004;58:710-711.

16. Clarkin N, Wynne R. Vocational Rehabilitation and Work Resumption: A Review of the Literature. Dublin: Work Research Centre; 2003. Report to the EU. Available from: www.surrey.ac.uk/Psychology/stress-impact. Accessed December 1, 2007.

17. Prins R. Mental health problems and disability pensions: trends and measures in a cross-national perspective. J Public Health. 2006;14:371-375.

18. Blonk RWB, Brenninkmeijer V, Lagerveld SE, Houtman ILD. Return to work: a comparison of two cognitive behavioural interventions in cases of work-related psychological complaints among the self-employed. Work Stress. 2006;20:129-144.

19. Ahlgren A, Bergroth A, Ekholm J, Schuldt K. Work resumption after vocational rehabilitation: a follow-up two years after completed rehabilitation. Work. 2007;28:343-354.

20. D'Amato A, Zijlstra FRH. Occupational stress: A review of the literature relating to mental health. Guildford: University of Surrey; 2003. Report to the EU. Available from: www.surrey.ac.uk/Psychology/stress-impact. Accessed December 1, 2007.

21. Karasek RA, Theorell T. Healthy Work- Stress, Productivity, and the Reconstruction of Working Life. New York: Basic Books; 1990.

22. Karasek RA. Job demands, job decision latitude, and mental strain: implications for job redesign. Adm Sci Q. 1979;24:285-308.

23. Hignett S, Wilson JR, Morris W. Finding ergonomic solutions-participatory approaches. Occup Med. 2005;55:200-207.

24. McNamee R, Carder M, Moeny A, Agius R. Time trends in the incidence of work-related disease in the UK, 1996-2006: estimation from ODIN/THOR surveillance data. 2007. Report of University of Manchester. Available from: http://www.medicine.manchester.ac.uk./coeh/. Accessed March 1, 2008

25. Henderson M, Glozier N, Elliott KH. Long term sickness absence. BMJ. 2005;330:802-803.

26. Leiter M, Zanaletti W, Argentero P. Occupational risk perception, safety training, and injury prevention: testing a model in the Italian printing industry. J Occup Health Psychol. 2009;14:1-10.

27. Ajzen I, Fishbein M. Understanding Attitudes and Predicting Social Behavior. Englewood Cliffs, NJ: Prentice-Hall; 1980.

28. Ajzen I. From intentions to actions: a theory of planned behavior. In: Kuhl J, Beckman J, eds. Action-Control: From Cognition to Behavior. Heidelberg, Germany: Springer; 1985:11-39.

29. Ajzen I. The theory of planned behavior. Organ Behav Hum Decis Process. 1991;50:179-211.

30. Nieuwenhuijsen K, Verbeek JH, de Boer AG, Blonk RWB, van Dijk FJH. Supervisory behaviour as a predictor of return to work in employees absent from work due to mental health problems. Occup Environ Med. 2004;61: $817-823$

31. Burdorf A, Naaktgeboren B, Post W. Prognostic factors for musculoskeletal sickness absence and return to work among welders and metal workers. Occup Environ Med. 1998;55:490-495.

32. Alexopoulus EC, Burdorf A. Prognostic factors for respiratory sickness absence and return to work among blue collar workers and office personnel. Occup Environ Med. 2001;58:246-252.

33. Van den Klink JJ, Blonk RW, Schene AH, van Dijk FJ. Reducing long term sickness absence by an activating intervention in adjustment disorders: a cluster randomized controlled design. Occup Environ Med. 2003;60:429437.

34. Shrey DE, Mital A. Accelerating the return to work (RTW) chances of coronary heart disease (CHD) patients: part 2-development and validation of a vocational rehabilitation programme. Disabil Rehabil. 2000;22:621-626.

35. Bandura A. Self-efficacy: The Exercise of Control. New York: Freeman; 1997.

36. Salanova M, Peiro JM, Schaufeli W. Self-efficacy specificity and burnout among information technology workers: an extension of the job demandcontrol model. Eur J Work Organ Psychol. 2002;11:1-25.

37. Faucett J, Blanc PD, Yelin E. The impact of carpal tunnel syndrome on work status: implications of job characteristics for staying on the job. J Occup Rehabil. 2000;10:55-69.

38. Shaw WS, Huang Y. Concerns and expectations about returning to work with low back pain: identifying themes from focus groups and semistructured interviews. Disabil Rehabil. 2005;27:1269-1281.

39. Millward LJ, Lutte A, Purvis RG. Depression and the perpetuation of on incapacitated identity as an inhibitor of return to work. J Psychiatr Ment Health Nurs. 2005;12:565-573. 
40. Ruiz-Quintanilla SA, Wilpert B. The meaning of working-scientific status of a concept. In: de Keyser V, Qvale T, Wilpert B, Ruiz-Quintanilla SA, eds. The Meaning of Work and Technological Options. Chichester, England: John Wiley \& Sons; 1988:3-14.

41. Janssen N, van den Heuvel WPM, Beurskens AJ, Nijhuis FJN, Schroer CAP, van Eijk JTM. The Demand-Control-Support model as a predictor of return to work. Int J Rehabil Res. 2003;26:1-9.

42. Woods V. Work-related musculoskeletal health and social support. Occup Med. 2005;55:177-189.

43. Van Vuuren T. Wat maakt reïntegratie van langdurig zieken in het Midden en Kleinbedrijf tot een succes? In: Bleichrodt N, van der Flier H, Koopman $\mathrm{P}$, eds. Werken en laten werken: Bijdragen vanuit de Arbeids en Organisatiepsychologie. Houten: Bohn Stafleu Van Loghum; 2002.

44. James LA, James LR. Integrating work environment perceptions: explorations into the measurement of meaning. J Appl Psychol. 1989;74:739-751.

45. Schneider B. Organizational Climate and Culture. San Francisco: JosseyBass; 1990:5-39.

46. Schneider B, White S, Paul M. Linking service climate and customer perceptions of service quality: test of a causal model. J Appl Psychol. 1998;83:150-163.

47. Burke MJ, Borucki CC, Kaufman JD. Contemporary perspectives on the study of psychological climate: a commentary. Eur J Work Organ Psychol. 2002;11:325-340.

48. Schneider B, Salvaggio AN, Subirats M. Climate strength: a new direction for climate research. J Appl Psychol. 2002;87:220-229.

49. Zohar D. Safety climate in industrial organizations: theoretical and applied implications. J Appl Psychol. 1980;65:96-102.

50. Klein KJ, Conn AB, Sorra JS. Implementing computerized technology: an organizational analysis. J Appl Psychol. 2001;86:811-824.

51. Forehand GA, Von Haller G. Environmental variation in studies of organizational behavior. Psychol Bull. 1964;62:361-382.

52. D'Amato A, Zijlstra FRH. Psychological climate and individual factors as antecedents of work outcomes. Eur J Work Organ Psychol. 2008;17:33-54.

53. Hunt SM, McEwen J, McKenna SP. Measuring health status: a new tool for clinicians and epidemiologists. J R Coll Gen Pract. 1985;35:185-188.

54. Schwarzer R. Self-Efficacy: Thought Control of Action. Washington DC: Hemisphere Publishing Corporation; 1992.

55. Demerouti E, Bakker AB, Vardakou I. The convergent validity of two burnout instruments: a multitrait-multimethod analysis. Eur J Psychol Assess. $2003 ; 19: 12-23$.

56. Radloff LF. The CES-D Scale: a self-report depression scale for research in the general population. Appl Psychol Meas. 1977;1:385-401.

57. Bouma J, Ranchor AV, Sanderman R, van Sonderen E. Het meten van symptomen van depressie met de CES-D-een handleiding. Noordelijk Centrum voor Gezondheidsvraagstukken: Rijks Universiteit Groningen; 1995.

58. Holmes TH, Rahe RH. The social readjustments rating scales. J Psychosom Res. 1967;11:213-218.
59. Karasek R, Brisson C, Kawakami N. The Job Content Questionnaire (JCQ): an instrument for internationally comparative assessments of psychosocial job characteristics. J Occup Health Psychol. 1998;3:322-355.

60. Siegrist J. Adverse health effects of high-effort/low-reward conditions. J Occup Health Psychol. 1996;1:27-41.

61. Nagy MS. Using a single item approach to measure facet job satisfaction. $J$ of Occup Organ Psychol. 2002;75:77-86.

62. Elo A-L, Leppänen A, Jahkola A. Validity of a single-item measure of stress symptoms. Scand J Work Environ Health. 2003;29:444-451.

63. D'Amato A, Zijlstra FRH, Pierce J. Impact of Changing Social Structures on Stress and Quality of Life: Individual Perspective. Guildford: University of Surrey; 2005. Report to the EU. Available from: www.surrey.ac.uk/Psychology/ stress-impact. Accessed December 1, 2007.

64. Ilmarinen J. Aging Workers in the European Union-Status and Promotion of Work Ability, Employability, and Employment. Helsinki: Finnish Institute of Occupational Health; 1999.

65. Tuomi K, Illmarinen J, Jahkola A, Katajarinne L, Tulkki A. Work Ability Index. 2nd ed. Helsinki: Finnish Institute of Occupational Health; 1998.

66. Harpaz I. The factorial structure of the meaning of work. Hum Relat. 1986;39:595-614.

67. Field A. Discovering Statistics Using SPSS. London: Sage Publications; 2005

68. Xu Y, Ouyang Y, Luo X, Lu X, Yang X. The effect of demographic and social factors on return to work of injured workers with musculoskeletal disorders. Work. 2008;30:91-95.

69. Hansena A, Edlundb C, Henningssonc M. Factors relevant to a return to work: a multivariate approach. Work. 2006;26:179-190.

70. Dollard MF, Winefield AH, Winefield HR, eds. Occupational Stress in the Service Professions. London: Taylor and Francis; 2003.

71. Breslin FC, Pole JD, Tompa E, Amick BC III, Smith P, Johnson SH. Antecedents of work disability absence among young people: a prospective study. Ann Epidemiol. 2007;17:814-820.

72. Wynne R. System Level Responses to Stress Related Absence. Presented at: International Forum on Disability Management, Maastricht, 13-15 September; 2004. Available from: www.surrey.ac.uk/Psychology/stress-impact. Accessed December 1, 2007.

73. Schaufeli WB, Entzmann D. The Burnout Companion to Research and Practice: A Critical Analysis. London: Taylor \& Francis; 1998.

74. Hoogduin CAL, Schaufeli WB, Schaap CPDR, Bakker AB. Behandelingsstrategieën bij Burnout (Intervention and Treatment Strategies With Burnout). Houten: Bohn Stafleu van Loghum; 2001.

75. French JRP, Caplan RD, Harrison RV. The Mechanisms of Job Stress and Strain. New York, NY: Wiley; 1982.

76. Hardy GE, Woods D, Wall TD. The impact of psychological distress on absence from work. J Appl Psychol. 2003;88:306-314. 